
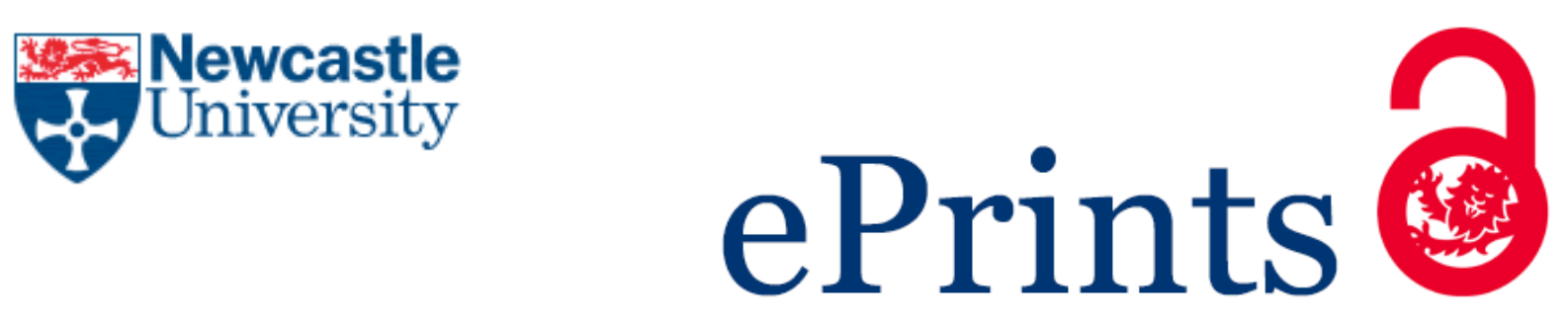

\author{
Thompson H, Angelova A, Bowler B, Jones M, Gutierrez T. \\ Enhanced crude oil biodegradative potential of natural phytoplankton- \\ associated hydrocarbonoclastic bacteria. \\ Environmental Microbiology 2017, 19(7), 2843-2861.
}

\title{
Copyright:
}

This is the peer reviewed version of the following article: Thompson $H$, Angelova A, Bowler B, Jones $M$, Gutierrez T. Enhanced crude oil biodegradative potential of natural phytoplankton-associated hydrocarbonoclastic bacteria. Environmental Microbiology 2017, 19(7), 2843-2861, which has been published in final form at https://doi.org/10.1111/1462-2920.13811. This article may be used for noncommercial purposes in accordance with Wiley Terms and Conditions for Self-Archiving.

DOI link to article:

https://doi.org/10.1111/1462-2920.13811

Date deposited:

$25 / 08 / 2017$

Embargo release date:

05 June 2018 


\section{Enhanced crude oil biodegradative potential of natural phytoplankton-associated}

\section{2 hydrocarbonoclastic bacteria}

4 Haydn Thompson ${ }^{1}$, Angelina Angelova ${ }^{1}$, Bernard Bowler ${ }^{2}$, Martin Jones ${ }^{2}$, Tony Gutierrez ${ }^{1 *}$ 5

$6 \quad{ }^{1}$ School of Life Sciences, Heriot Watt University, Edinburgh, UK

$7 \quad{ }^{2}$ School of Civil Engineering and Geosciences, University of Newcastle, Newcastle Upon Tyne, UK

10 *Correspondence to:

11 Dr. Tony Gutierrez

12 School of Life Sciences, Heriot-Watt University, Edinburgh EH14 4AS, U.K.

13 tony.gutierrez@hw.ac.uk

15 Running title: Phytoplankton-bacterial biodegradation of crude oil PAHs

17 Keywords: eukaryotic phytoplankton; hydrocarbon-degrading bacteria (HCB); crude oil; micro-

18 algae; biodegradation; marine environment

21 The authors declare no conflict of interest. 


\section{Summary}

27 Phytoplankton have been shown to harbour a diversity of hydrocarbonoclastic bacteria (HCB), yet it

28 is not understood how these phytoplankton-associated HCB would respond in the event of an oil spill

29 at sea. Here, we assess the diversity and dynamics of the bacterial community associated with a

30 natural population of marine phytoplankton under oil spill-simulated conditions, and compare it to

31 that of the free-living (non phytoplankton-associated) bacterial community. Whilst the crude oil

32 severely impacted the phytoplankton population and was likely conducive to marine oil snow (MOS)

33 formation, analysis of the MiSeq-derived 16S rRNA data revealed dramatic and differential shifts in

34 the oil-amended communities that included blooms of recognized HCB (e.g. Thalassospira,

35 Cycloclasticus), including putative novel phyla, as well as other groups with previously unqualified

36 oil-degrading potential (Olleya, Winogradskyella, and members of the inconspicuous BD7-3

37 phylum). Notably, the oil biodegradation potential of the phytoplankton-associated community

38 exceeded that of the free-living community, and it showed a preference to degrade substituted and

39 non-substituted polycyclic aromatic hydrocarbons. Our study provides evidence of

40 compartmentalization of hydrocarbon-degrading capacity in the marine water column, wherein HCB

41 associated with phytoplankton are better tuned to degrading crude oil hydrocarbons than that by the

42 community of planktonic free-living bacteria. 


\section{Introduction}

53 Marine eukaryotic phytoplankton (micro-algae) contribute significantly to life on Earth by

54 performing approximately half of global carbon fixation (Ducklow et al., 2001) and producing

55 almost half of the oxygen in the atmosphere (Field et al., 1998). As protagonist members at the base

56 of the food chain, they contribute a key role to the ecology of the marine ecosystem. Though still an

57 area in a nascent state of our understanding, the interaction of phytoplankton with bacteria, which

58 primarily occurs on the cell surface of phytoplankton cells (i.e. phycosphere), is thought to play

59 importantly to their ecological success (Buchan et al., 2014; Amin et al., 2012; Amin et al., 2015).

60 Archaea may also play a pivotal role in phytoplankton dynamics and functioning, as evidenced in some recent reports (Orsi et al., 2015; Needham and Fuhrman, 2016), but they have largely been ignored in this regard. Within an algal-bacterial community, the bacteria are likely to utilize algal exudates as carbon and energy sources (Bell and Mitchell, 1972; Myklestad, 1995), whereas the phytoplankton could benefit through bacterially mediated trace metal/nutrient bioavailability (McGenity et al., 2012). Amin and colleagues (2009), for example, showed a mutual sharing of iron and fixed carbon between several species of phytoplankton and bacteria, whereas Kazamia and colleagues (2012) reported the supply of bacterial-produced vitamin B12 to the eukaryote partner in exchange for fixed carbon. The fact that very few phytoplankton species can be maintained, or subcultured for long periods, in an axenic state (i.e. devoid of their bacterial symbionts) in the laboratory is testament to the important role that the associated bacterial, and possibly likely also archaeal, community plays in their overall success.

Members of three major phytoplankton lineages (dinoflagellates, diatoms, coccolithophores) have been found to harbour obligate and generalist hydrocarbonoclastic bacteria (HCB), including novel taxa of these organisms (Green et al., 2006; Gutierrez et al., 2012a,b; 2013b; 2014). The association of $\mathrm{HCB}$ with phytoplankton raises important questions with respect to their evolutionary genesis, ecology and response of these bacteria during a marine oil spill, and whilst the underlying basis for this remains to be defined, there is evidence suggesting that the enrichment of hydrocarbons 
on phytoplankton cell surfaces plays an important role. By nature of their surface chemistry, phytoplankton cell surfaces have been shown to adsorb and accumulate polycyclic aromatic hydrocarbon (PAH) molecules (Mallet \& Sarfou, 1964; Andelman and Suess 1970). Phytoplankton may also be a biogenic source of PAHs by synthesizing these compounds (Andelman and Suess, 1970; Gunnison and Alexander, 1975) and translocating them into the algal cell wall (Gunnison and Alexander, 1975; Zelibor et al., 1988). Compared to the surrounding seawater, phytoplankton cell surfaces can thus become enriched with PAHs, and attract PAH-degrading bacteria to an available source of carbon and energy. Many phytoplankton also produce long-chain hydrocarbon-like compounds, such as alkenones (Marlowe et al., 1984), and almost all produce the volatile hydrocarbon isoprene (Shaw et al., 2010; Exton et al., 2012) which could explain the occurrence of HCB found associated with these organisms. Whether through biogenic synthesis or adsorption of PAH molecules from the surrounding seawater, the cell surface of phytoplankton cells in the marine water column may act as a "hot spot" to which PAH-degrading bacteria exist, potentially in symbiotic relationship.

There are several factors about HCB living associated with phytoplankton that should be taken into account when these organisms come into contact with petrochemicals at sea. Oil contamination, particularly from large oil spills, is an important stressor that can significantly influence phytoplankton biomass. In general, field and laboratory studies have shown that crude oil concentrations up to $1.0 \mathrm{mg} / \mathrm{L}$ can stimulate phytoplankton growth - a phenomenon that may have an origin in ocean systems distinguished by the occurrence of natural hydrocarbon seeps on the sea

98 floor where elevated surface chlorophyll concentrations have been reported (D'souza et al., 2016).

99 Higher crude oil concentrations, however, can cause anywhere from slight, severe to complete 100 growth inhibition of phytoplankton (Nomura et al., 2007; Adekunle et al., 2010; Gilde and Pinckney, 101 2012; Gonzàlez et al., 2013; Paul et al., 2013; Ozhan et al., 2014; Ozhan and Bargu, 2014a,b). The 102 consequences of crude oil pollution at sea to phytoplankton must also take into account the 103 associated bacterial community. Quite often, however, attention has focused to study one or the other 
104 of these organisms. To take the Deepwater Horizon (DWH) oil spill as a recent example, the various

105 reports that had investigated the effects of the Macondo oil to phytoplankton populations in the Gulf

106 of Mexico during the spill did not focus on the associated bacterial community (Ozhan and Bargu,

107 2014a,b; Ozhan et al., 2014; Parsons et al., 2015), whereas the bacterial response had been

108 independently investigated in other studies (e.g. Bælum et al., 2012; Hazen et al., 2010; Gutierrez et

109 al., 2013c; Yang et al., 2016). These and a plethora of other studies that have employed seawater

110 sampling programs to study microbial population diversity and dynamics do not often employ

111 operational fractionation to tease apart the various microbial populations (based on size) that

112 constitute the water sample, hence leading to the misconception that HCB identified in any given

113 water column sample may have existed in a free-living state. It is not inconceivable that many of the

114 HCB identified in the plethora of reports in the literature describing their isolation, molecular

115 identification and/or dynamics, were likely physically attached to phytoplankton cells at the time of

116 their collection from the marine environment. Indeed, HCB associated with phytoplankton in marine

117 systems has largely been ignored.

118 A notable product from the interaction of oil with phytoplankton and their associated HCB

119 and other bacterial groups is the formation of marine oil snow (MOS). MOS was a distinguishing

120 feature to the DWH oil spill that is defined as mucilaginous organic matter with a "fluffy" or

121 gelatinous off-white appearance. Its formation has been reported to involve the interaction of

122 phytoplankton cells (Passow et al., 2012), bacterial cells (Fu et al., 2014; Arnosti et al., 2015) and

123 extracellular polymeric substances (EPS) (Gutierrez et al., 2013a; Passow et al., 2012; Arnosti et al.,

124 2015; Ziervogel et al., 2012) with dissolved hydrocarbons and/or emulsified oil droplets (Passow et

125 al., 2012; Ziervogel et al., 2012). MOS formation has in fact been reported to be more prominent

126 with bacterial-phytoplankton communities (Fu et al., 2014; van Eenennaam et al., 2016) compared to

127 when phytoplankton or bacterial cells are independently exposed to oil (van Eenennaam et al., 2016).

128 EPS primarily produced by certain species of phytoplankton and bacteria can act as a 'sticky glue' in

129 binding particulates, such as microbial cells, in seawater (Wotton, 2004). Recent work has shown 
130 that bacteria associated with phytoplankton contribute significantly to the bulk of EPS produced in 131 seawater (van Eenennaam et al., 2016), and that this bacterial-derived EPS is likely the main type of

132 'glue' in the formation of MOS (Gutierrez et al., 2013; van Eenennaam et al., 2016).

133 In light of increasing evidence showing the occurrence of HCB associated with marine

134 phytoplankton, there is a paucity of knowledge that explains this algal-bacterial partnership and what

135 role it plays during an oil spill at sea. The degradation of oil hydrocarbons has been demonstrated

136 with artificial phytoplankton-bacterial consortia (Safanova et al., 1999; Borde et al., 2003; Muñoz et

137 al., 2003; Warshawsky et al., 2007). Taking into account the intimate relationship that exists

138 between phytoplankton and bacteria, including hydrocarbon-degraders, and the fact that enhanced

139 degradation of hydrocarbons has been demonstrated when bacteria and phytoplankton coexist (e.g.,

140 Abed and Köster, 2005; Warshawsky et al., 2007), studies aimed to investigate the microbial

141 response to an oil spill at sea would be greatly informed by assessing the phytoplankton-bacterial

142 community as a complete microbiological unit. In a recent study, Mishamandani et al. (2015)

143 showed that the bacterial community associated with a laboratory culture of the marine diatom

144 Skeletonema costatum is tuned to respond to and degrade aromatic hydrocarbons when challenged

145 with crude oil. Transposing this investigation to the field, here we conducted an oil spill-simulated

146 experiment with a natural phytoplankton-bacterial assemblage from the west coast of Scotland. The

147 field sample was operationally fractioned to isolate the phytoplankton community from the free-

148 living (non-associated) bacterial population, and both fractions then used to examine their response

149 to crude oil. Sequencing of the 16S ribosomal RNA (rRNA) gene amplicons with the Illumina MiSeq

150 technology was used to monitor the dynamics of the bacterial community and of HCB taxa in both

151 oil-amended and non-amended incubations. Further, hydrocarbon analysis of oil extracts was used to

152 assess the biodegradative potential of the community compared to the free-living bacterial fraction

153 and infer their possible contribution to the overall biodegradation of the oil. 


\section{Results}

158 To examine the microbial response and potential of phytoplankton-associated HCB communities

159 from the west coast of Scotland on the biodegradation of crude oil, two oil enrichment treatments

160 were set up. The first constituted the phytoplankton community (PHY) with its associated bacterial

161 symbionts from Loch Creran surface water, whereas the second treatment comprised solely the free-

162 living bacterial fraction (BAC) with phytoplankton removed by filtration; each of the PHY and BAC

163 treatments were amended with Heidrun crude oil. A control treatment (CON) was also set up in the

164 exact same way as treatment PHY, with the exception that the oil was not added.

\section{Degradation of Heidrun crude oil}

167 Student's T-tests confirmed that there were significant $(P<0.05)$ differences between the controls

168 and PHY treatments for 5 of the hydrocarbon ratios analysed (Figure 1), specifically in reductions for 169 both $n \mathrm{C}_{17}$ and $n \mathrm{C}_{18}$ aliphatic hydrocarbons and reductions in 2-methylnaphthalene and phenanthrene.

170 In the BAC treatments, significant $(P<0.05)$ reductions compared to their controls in just a single

171 parameter were indicative of biodegradation (i.e. 2-methylnaphthalene/2,6+2,7-dimethylnaphthalene

$172[2 \mathrm{MN} / 26+27 \mathrm{DMN}]$ ) (Figure 1). These results suggested that biodegradation had occurred to a

173 greater extent in the PHY (with phytoplankton) than in BAC (without phytoplankton) treatments for 174 both aliphatic and aromatic hydrocarbons.

In the crude oil enrichment incubations with the phytoplankton (treatment PHY) or with the

176 free-living bacterial fraction (treatment BAC), we determined the concentrations of various aliphatic 177 and aromatic hydrocarbon species at the termination of the experiment (day 40). For this, the total 178 volume of each of the 12 cultures that were designated for hydrocarbon analysis were extracted and analysed for total petroleum hydrocarbons (TPH) and their hydrocarbon composition, as described below. Compared with acid-inhibited controls, the concentrations of some hydrocarbon species were

181 found to have significantly decreased $(P<0.05)$ after 40 days in the uninhibited (no acid treated) 
182 incubations, and therefore was attributed to microbial biodegradation. Table 1 shows these

183 hydrocarbons that were significantly biodegraded, and the percentage they were biodegraded

184 compared to their concentrations in acid-inhibited controls. Of a total of $28 n$-alkanes analysed $\left(n \mathrm{C}_{8}-\right.$

$185 n \mathrm{C}_{35}$ ), nine had been significantly degraded (i.e. $n \mathrm{C}_{20}-n \mathrm{C}_{25}, n \mathrm{C}_{27}, n \mathrm{C}_{28}$ and $n \mathrm{C}_{31}$ ) in treatment $\mathrm{PHY}$,

186 whereas eight $n$-alkanes (i.e. $n \mathrm{C}_{16}, n \mathrm{C}_{17}, n \mathrm{C}_{19}-n \mathrm{C}_{24}$ ) were significantly biodegraded in treatment

187 BAC (Table 1). Some of the low-molecular-weight $n$-alkanes, such as $n \mathrm{C}_{8}, n \mathrm{C}_{9}$ and $n \mathrm{C}_{10}$, were not

188 detected in extracts from both the live and acid-inhibited incubations, suggesting they were likely

189 lost by both evaporation and biodegradation over the course of the experiment. Similarly to the

190 biodegradation of $n$-alkanes in these two treatments, more types of aromatic species (a total of 15

191 identified) were biodegraded in treatment PHY compared to twelve that were significantly

192 biodegraded in treatment BAC (Table 1). The fifteen measured aromatic species biodegraded in 193 treatment PHY included dibenzothiophene, 4-methyldibenzothiophene, $\mathrm{C}_{28} \mathrm{~S}$-triaromatic steroid and 194 several substituted species of naphthalene and phenanthrene. Overall, the BAC treatments displayed

195 a preference for biodegrading the low-molecular-weight fraction of $n$-alkanes and aromatics

196 compared to the PHY treatments which exhibited a preference for the higher-molecular-weight

197 species.

Phytoplankton and bacterial cell population dynamics

200 The phytoplankton community in water samples from Loch Creran was comprised of a diversity of

201 dinoflagellates and mainly diatoms, in particular species of Thalassiosira, Chaetoceros and

202 Skeletonema (Table 2). Dominance was based on a cell count of $\geq 10^{6}$ cells ${ }^{-1}$ for each species/genus

203 identified. These diatoms are cosmopolitan and typically found to dominate the phytoplankton

204 community in surface waters during the spring on the west coast of Scotland (Fehling et al., 2006;

205 Lappalainen and Tett, 2014).

To assess the phytoplankton community dynamics in response to crude oil, changes in

207 Chlorophyll $a(\mathrm{Chl} a)$ were determined (Figure 2). In treatment $\mathrm{CON}$ without crude oil (incubations 
$208 \mathrm{C} 1, \mathrm{C} 2, \mathrm{C} 3), \mathrm{Chl} a$ concentrations increased at a rate of $5.8 \mu \mathrm{g} \mathrm{l}^{-1} \mathrm{day}^{-1}$, from initial values of $7.1 \pm$

$2091.5 \mu \mathrm{g} \mathrm{l}^{-1}$ at day 0 and reached maximum levels of $54.0 \pm 3.7 \mu \mathrm{g}^{-1}$ at day 8 (Figure $2 \mathrm{C}$ ). Thereafter,

210 Chl $a$ concentrations decreased sharply at $8.3 \mu \mathrm{g}^{-1}$ day $^{-1}$ within 3 days and continuing to decrease

211 thereafter at an average rate of $1.0 \mu \mathrm{g}^{-1}$ day $^{-1}$ and reaching $3.1 \pm 2.9 \mu \mathrm{g} \mathrm{l^{-1 }}$ at day 40 . Conversely, no

212 increase in Chl $a$ concentrations were measured in the acid-inhibited controls as was expected

213 (results not shown). The presence of crude oil in treatment PHY (incubations P1, P2, P3), however,

214 had a marked effect on Chl $a$ concentrations compared to the untreated control incubations

215 (treatment CON). In the presence of the oil, phytoplankton growth was totally suppressed from the

216 commencement of the experiment when the oil was added, with $\mathrm{Chl} a$ concentrations decreasing at a

217 rate of $0.6 \mu \mathrm{g}^{-1}$ day $^{-1}$, from initial values of $8.5 \pm 0.5 \mu \mathrm{g}^{-1}$ at day 0 to $0.7 \pm 0.2 \mu \mathrm{g}^{-1}$ at day 14 , and

218 thereafter remaining at these levels until the termination of the experiment (Figure 2A). Microscopic

219 examination of the culture liquid from treatment PHY did not reveal any live phytoplankton cells

220 after 7 days following addition of the crude oil; intact cells showed signs of bleaching, and much of

221 the phytoplankton population in this treatment had formed into flocs or aggregates (aka MOS) that

222 persisted until the termination of the experiment. Similar observations were recorded in treatment

223 CON, but much later (after day 20) in these incubations. Phytoplankton population dynamics via Chl

$224 a$ analysis were highly concordant with the abundance of 16S rRNA genes of chloroplasts (from our

225 Illumina MiSeq analysis below) across the three treatments (results not shown).

Quantification of bacterial 16S rRNA genes in each of the three treatments (PHY, BAC,

227 CON) was measured as a proxy for bacterial biomass; this method was used because accurate DAPI

228 counts for prokaryotic abundance were, as explained above, impossible to obtain. As shown in

229 Figure 2, bacterial 16S rRNA gene abundance across all three treatments decreased from day 0 . The

230 dynamic of bacterial gene abundance over the course of these 40-day experiments was similar

231 between the phytoplankton (PHY; Figure 2A) and free-living bacterial (BAC; Figure 2B) treatments

232 amended with oil, although it decreased approximately $25 \%$ more in the latter treatment. Conversely,

233 the dynamic of bacterial 16S rRNA gene abundance in the phytoplankton control treatment without 
234 oil (CON; Figure 2C) was markedly different, and showed a sharper drop in abundance within 5 days

235 compared to that in the PHY and BAC treatments. Thereafter, bacterial 16S rRNA gene abundance

236 increased over the next 3 days, then plateaued over the following 6 days, and then gradually

237 decreased until the termination of the experiment; by day 40 abundance values were one order of

238 magnitude lower compared to initial concentrations (Figure 2C). Visually the oil-treated incubations

239 with phytoplankton (treatment PHY) became gradually more turbid, albeit slightly, over the course

240 of the experiment when compared to the incubation with just the bacteria (treatment BAC) and, more

241 so, the untreated control (treatment CON). This increase in turbidity would be assumed indicative of

242 bacterial growth, possibly by the enrichment of HCB feeding on hydrocarbon components of the oil.

243 The gradual decrease in bacterial 16S rRNA genes in the PHY treatment (Figure 2A), however,

244 suggests that this increase in turbidity was less due to an increase in bacterial biomass, but likely

245 from the emulsification of the oil into dispersed oil droplets.

MiSeq sequencing of bacterial community diversity and dynamics

248 The diversity and response of the bacterial communities to crude oil was assessed in two replicates

249 for each of treatments PHY, BAC and CON using Illumina MiSeq technology. This was performed 250 at days $0,8,14,24$ and 40 . Initially at day 0 , the bacterial community in all the three treatments was 251 composed mainly of members within the Gammaproteobacteria, which was dominated by

252 Pseudoalteromonadaceae and Vibrionaceae - 71-78\% combined contribution to the total 16S rRNA

253 gene sequence reads in each library - with minority representation from Piscirickettsiaceae,

254 Oceanospirillales, Methylococcales and several members of the Order Alteromonadales (additional

255 to Pseudoalteromonadaceae) that included Psychromonadaceae, Colwelliaceae and

256 Alteromonadaceae (Figure 3; Suppl. Table S1). The community also included minority

257 representation $(<3 \%)$ from Rhodobacterales and Flavobacteriales of the classes Alphaproteobacteria 258 and Bacteroidetes, respectively, and of the Phylum Verrucomicrobia. By day 8, the abundance of the

259 Pseudoalteromonadaceae and Vibrionaceae dramatically decreased by at least $50 \%$ in all three 
260 treatments (as much as 95\% for Pseudoalteromonadaceae in treatment CON) compared to their

261 initial abundance at day 0 , and their abundance continued to decrease gradually thereafter until the

262 termination of the experiment (day 40 ) reaching low $(<0.6 \%)$ to undetectable levels. Over the

263 duration of the experiment, the dominant members of the community in each of the three treatments

264 (PHY, BAC, CON) belonged to the Piscirickettsiaceae, Alteromonadaceae, Rhodobacterales and

265 Flavobacteriales.

Following addition of the oil to treatments PHY and BAC, the community changed markedly

267 within 8 days relative to the control (treatment CON) with no oil added. At this time-point, the

268 Piscirickettsiaceae, and to a lesser extent Oceanospirillaceae (incl. other Oceanospirillales),

269 Colwelliaceae and Flavobacteriales showed a marked increase in abundance and were the major

270 dominating groups in these oil-amended treatments. By days 14 and 24, the most dominant and

271 enriched groups in treatments PHY and BAC were members of the Piscirickettsiaceae and to a lesser

272 extent Oceanospirillaceae and Colwelliaceae. By day 40, the dominant groups in treatments PHY

273 and BAC were members of the Piscirickettsiaceae. By day 40, the BD7-3 had gradually increased in

274 abundance in treatment PHY over the duration of the experiment, whereas in treatment BAC

275 members of the Kiloniellales became a dominant contributing group at day 40. The Bacteroidetes

276 increased in abundance over the course of the experiment in only treatment CON. Overall, 20

277 operational taxonomic units (OTUs) were identified to have become enriched by the oil (Figure 4).

278 Of the Gammaproteobacteria, these were OTU-6 (Cycloclasticus), OTU-7 (members of the

279 Colwelliaceae), OTU-8 (other members of the Priscirickettsiaceae), OTU-9 (Methylophaga), OTU-

28010 (Oleispira), OTU-11 (Marinomonas), OTU-12 (Alcanivorax), OTU-13 (Halomonas), OTU-14

281 (Shewanella) and OTU-15 (Psychromonas); of the Alphaproteobacteria, OTU-1 (Order BD7-3),

282 OTU-2 (Hyphomonadaceae), OTU-3 (other members of the Rhodobacteraceae), OTU-4

283 (Thalassospira), OTU-5 (Phaeobacter); of the Betaproteobacteria, OTU-19 (Methylotenera); of the

284 Bacteroidetes, OTU-16 (other members of Flavobacteriaceae), OTU-17 (Olleya), OTU-18

285 (Winogradskyella); and of the Verrucomicrobia, OTU-20 (Verrucomicrobium). As shown in Figure 
4, OTU-9 (Methylophaga) showed the strongest succession pattern in both treatments PHY and

$\mathrm{BAC}$, starting from day 8 and peaking in relative abundance by day14. The $16 \mathrm{~S}$ rRNA gene sequences, including sequences belonging to related HCB (Figure 5).

\section{Discussion}

The Loch Creran phytoplankton community was severely impacted when exposed to crude oil, as Chl $a$ concentrations decreased immediately following exposure and reached near undetectable levels after 14 days. This is in concordance with the impact that the Macondo oil had upon the phytoplankton community in the Gulf of Mexico during the active phase of the DWH oil spill, which resulted in $85 \%$ reduction of phytoplankton abundance relative to baseline levels from previous years (Parsons et al., 2015). The phytoplankton that survived the DWH perturbation represented a community with a reduced diversity that was dominated by diatoms and cyanobacteria (Parsons et al., 2015). The Loch Creran phytoplankton community, however, appeared to have been decimated by the oil, as microscopic observations of sub-samples taken from the oil-treated incubations (PHY) did not reveal any live phytoplankton cells. Supporting this, Chl $a$ concentrations 302 had decreased by $92 \%$ of initial values by day 14 in these incubations, and we suspect that the very 303 low residual Chl $a$ levels measured after day $14\left(\leq 0.7 \mu \mathrm{g} \mathrm{l}^{-1}\right)$ may be attributed to non-decomposed extracellular or intracellular Chl $a$ in dead or dying phytoplankton cells. Susceptibility of phytoplankton to oil varies among species, and whilst some species will thrive in oil-contaminated seawater, others will be detrimentally affected (González et al., 2009; Adekunle et al., 2010; Gilde and Pinckney 2012; Ozhan et al., 2014). It has been suggested that diatoms are more sensitive to 308 crude oil than other phytoplankton (Siron et al., 1991) because the external silica frustule has a high affinity for absorbing hydrocarbons, wherein these chemicals accumulate and result in toxicity to the 
311 Loch Creran phytoplankton community was dominated by diatoms, this might explain its decimation 312 upon exposure to the Heidrun crude oil.

314 sampling, which can cause mixing of the water column, including with the surficial sediment layer,

315 and potentially lead to replenishing the upper water column with nutrients. This nutrient input from

316 the sediment could explain the episodic increase and subsequent gradual decline of the

317 phytoplankton in the non-treated control incubations (CON). The bacterial population followed a

318 short-lived 'boom' and then 'bust' dynamics, which could have resulted from limited nutrient

319 concentrations in the Loch Creran water column. Nutrient limitation has also been shown to increase

320 the sensitivity of phytoplankton to crude oil (Ozhan and Bargu, 2014a; Karydis, 1981), which may in

321 part explain the dramatic decline in the phytoplankton population in the oil-amended incubations

322 (PHY). However, the extent to which phytoplankton are impacted by crude oil can largely depend on

323 the toxicological potency and concentration of the oil (Dunstan et al., 1975; Vargo et al., 1982; Bate

324 and Crafford, 1985; Huang et al., 2011). Different phytoplankton species can have varying

325 tolerances to oil (Ozhan and Bargu, 2014a,b), and some may even be stimulated by it (Prouse et al.,

326 1976; Jung et al., 2012; Parsons et al., 2015). The most toxigenic hydrocarbons in crude oils are

327 those comprising the aromatic fraction - i.e. mono-aromatics and PAHs - which are recognized as

328 high-priority pollutants to the environment (Agency for Toxic Substances and Disease Registry,

329 2007; Boehm and Page, 2007). Toxicological effects of aromatic hydrocarbons to phytoplankton, in

330 particular the PAHs (Harrison et al., 1986; Ozhan et al., 2014), have been reported in several studies

331 (Ostgaard et al., 1984a,b; Sargian et al., 2005; Huang et al., 2011); the toxicity of these chemicals to

332 phytoplankton have been reported at concentrations as low as $1 \mu \mathrm{g} \mathrm{L}^{-1}$ (Ozhan et al., 2014 and

333 references therein). Our analysis of the Heidrun crude oil used here showed it contained an aromatic

334 hydrocarbon content of $15 \%$ of TPH, comprised largely of relatively low-molecular-weight (e.g.

335 alkylated naphthalenes and phenanthrenes) PAHs that very likely contributed to the observed decline

336 in phytoplankton abundance in the oil-amended incubations. 
Hydrocarbon analysis revealed that biodegradation of the crude oil was enhanced in the PHY

338 incubations, as indicated by the the lower $n \mathrm{C}_{17} /$ pristane and the $n \mathrm{C}_{18} /$ phytane ratios in the PHY

339 treatments relative to the acid inhibited controls, along with also lower ratios for 2-

340 methylnaphthalene/1-methylnaphthalene, 2-methylnaphthalene/(2,6+2,7)-dimethylnaphthalene and

341 phenanthrene/9-methylphenanthrene (P/9MP). On the other hand, the ratios for only 2-

342 methylnaphthalene/(2,6+2,7)-dimethylnaphthalene were lower in the BAC treatments compared to

343 their respective acid-inhibited controls. Interestingly, triaromatic steroids appeared to be significantly

344 degraded in the PHY treatments, which was unexpected as these compounds are relatively

345 recalcitrant to biodegradation (Radović et al., 2014). However, their natural degradation has been

346 reported in some laboratory- and field-based studies (Barakat et al., 2002; Díez et al., 2005; Radović

347 et al., 2014). The degradation of these cholestane-derivatives may be contributed by phytoplankton-

348 associated bacteria encoding enzymes with a broad specificity for degrading cholesterols that can be

349 found in the cell membranes of marine diatoms (Ponomarenko et al., 2004). Notably, the

350 phytoplankton-associated bacterial community of the PHY treatments exhibited an enhanced ability

351 to degrade the oil, both in terms of the range and extent of hydrocarbon species degraded, as well as

352 a preference for biodegrading higher-molecular-weight hydrocarbons, compared to that by the free-

353 living community of the BAC treatments.

354 The formation of aggregated cells of phytoplankton and bacterial cells in the oil-amended

355 incubations is reminiscent of the formation of marine oil snow (MOS) that was observed in profuse

356 quantities in the Gulf of Mexico near the DWH spill site (Diercks et al., 2010; Passow et al., 2012).

357 Of the major phytoplankton groups, diatoms reportedly can play a role in MOS formation (Passow et

358 al., 1994). Diatoms are a dominant group of phytoplankton communities in Scottish coastal waters

359 (Leterme et al., 2006; McQuatters-Gollop et al., 2007), and they were a dominant group in the Loch

360 Creran water column when we sampled in May 2013 - predominantly Chaetoceros, Skeletonema and

361 Thalassiosira. Besides phytoplankton, there are several lines of evidence pointing to EPS-producing

362 bacteria in also playing a protagonistic role in MOS formation. Firstly, EPS can take the form of 
363 transparent exopolymer particles (TEP) that are recognized as a 'sticky glue', facilitating the 364 aggregation of microbial cells (phytoplankton, prokaryotes, fungi) to form marine snow (Alldredge 365 et al., 1993; Passow et al., 1994; Passow, 2002), or MOS in the presence of crude oil (Passow et al., 366 2012; Ziervogel et al., 2012; Gutierrez et al., 2013a). Secondly, certain groups of bacteria, such as 367 Halomonas (Gutierrez et al., 2013a), Pseudoalteromonas and Alteromonas (T. Gutierrez, M. Jones, 368 A.Teske, unpublished data), and Colwellia (Bælum et al., 2012) have been shown to play a role in 369 the formation of MOS, specifically via their production of EPS. Thirdly, a recent report by van 370 Eenennaam et al. (2016) implicates EPS-producing bacteria associated with phytoplankton as major 371 contributors in MOS formation; even more so than EPS produced by non-associated bacteria and 372 axenic phytoplankton. In the only published report to-date to have examined the microbial 373 communities associated with MOS, Arnosti et al., (2015) identified a diverse bacterial community on 374 MOS particles that was primarily composed of EPS-producing bacteria. Some of these taxa included 375 Cycloclasticus of the Piscirickettsiaceae, members within the Bacteroidetes, and diverse groups of 376 the Alphaproteobacteria (principally the Roseobacter clade) - organisms that were found enriched in 377 our oil-amended incubations with the Loch Creran phytoplankton-bacterial community. These

378 laboratory observations showing the formation of MOS might suggest that in the event of an oil spill in coastal and offshore waters of Scotland, MOS will be expected to form. How much of it could be 380 formed in these waterways and what environmental impact this could have after its settlement to the 381 seafloor remains unknown and warrants investigation considering that large areas of the Scottish 382 coast contain diverse and sensitive benthic communities (Moore et al., 1998; Bailey et al., 2011). 383 The bacterial community in the treatments was initially dominated by members of the

384 Vibrionaceae and Pseudoalteromonadaceae - groups that are typically found associated with marine 385 phytoplankton (Buchan et al., 2014) - and included putative oil-degrading taxa such as Colwellia, 386 although further work would be needed to confirm this. The control incubations, which did not 387 receive any oil $(\mathrm{CON})$, reflected a bacterial community diversity and dynamic that is typical of a 388 phytoplankton bloom in the field (Buchan et al., 2014), providing evidence to substantiate our 
389 experimental set-up in simulating in-situ environmental conditions. Whilst bacterial abundance is 390 generally positively correlated with the abundance of phytoplankton during a bloom (Chang et al.,

391 2003), there is often an initial decoupling between the two, as is often seen by a dramatic initial

392 decrease and then subsequent increase in bacterial abundance (Riemann et al., 2000). This was

393 indeed observed in the CON treatment, which comprised the phytoplankton community with its

394 bacterial symbionts, and although not fully understood it might result from bacterial competition

395 with phytoplankton for nutrients (Castberg et al., 2001). Since the phytoplankton, and its bacterial

396 symbiont, populations did not recover after this initial decoupling event, nutrient limitation is likely

397 to explain for this, as mentioned above. The community in the CON treatment became progressively

398 dominated by members of the phylum Bacteroidetes, in particular the group flavobacteria which

399 became more abundant during the decay phase, as is typically observed in the field (Simon et al.,

400 1999; Riemann et al., 2000; Pinhassi et al., 2004).

401 While the crude oil had detrimentally impacted the phytoplankton community, analysis of the

402 MiSeq-derived 16S rRNA sequences revealed dramatic shifts in the free-living bacterial community

403 (BAC treatment) and community associated with the phytoplankton (PHY treatment). After addition

404 of the oil, the community in the PHY incubations shifted and became dominated initially by

405 members of the Colwelliaceae (predominantly Colwellia) and the Oceanospirillaceae, including

406 Marinomonas and Alcanivorax. Alcanivorax are often strongly selected for in oil-impacted

407 environments (Head et al., 2006; Yakimov et al., 2007) and have been found associated with marine

408 phytoplankton (Green et al., 2004), whereas only a couple of studies have reported hydrocarbon-

409 degrading qualities for Marinomonas (Melcher et al., 2002; Dong et al., 2014). Hydrocarbon-

410 degrading Colwellia have also been reported to degrade hydrocarbons, such as strain RC25 that was

411 isolated from deep waters near the DWH spill site and for which there is evidence to suggest it may

412 have played a role in the formation of MOS during the spill (Bælum et al., 2012). These organisms

413 were thus the first to respond upon exposure to Heidrun crude oil and, as indicated by our

414 hydrocarbon analysis, may have contributed importantly to the degradation of the aromatic 
415 hydrocarbon fraction. The Piscirickettsiaceae, including Methylophaga, were also found

416 significantly enriched in both the PHY and BAC incubations. This is intriguing from the point of

417 view that Methylophaga have, until only recently, received little attention with respect to their role in

418 the degradation of hydrocarbons. This is because members of this genus are recognized for their

419 almost exclusive requirement for $\mathrm{C}_{1}$ sources (e.g. methanol, methylamine, dimethylsulfide) as sole

420 growth substrates, with the exception of some strains that are also capable of metabolising fructose

421 (Janvier and Grimont, 1995). Some studies have reported the enrichment of Methylophaga exposed

422 to oil or individual hydrocarbons in lab and field studies (Röling et al., 2002; Yakimov et al., 2005;

423 Coulon et al., 2007; Vila et al., 2010; Techtmann et al., 2015). Recent evidence showed that some

424 members of this genus are indeed capable of utilising hydrocarbons as a sole source of carbon and

425 energy (Mishamandani et al., 2014). Intriguingly, these previous studies showed what appeared to be

426 short-lived blooms of Methylophaga within the first few days after exposure to hydrocarbons,

427 whereas the enrichment of these organisms in our PHY and BAC incubations showed them to have

428 persisted until the termination of these experiments (day 40). Since Methylophaga, together with

429 other members of the Piscirickettsiaceae, were the organisms most strongly selected for in both oil-

430 amended incubations ( $\mathrm{PHY}$ and BAC), we posit that these organisms may have contributed a role in

431 the biodegradation of the Heidrun crude oil, particularly of the aromatic fraction. Since

432 phytoplankton can produce large quantities of extracellular high-molecular-weight dissolved organic

433 matter (DOM) that acts as a rich source of methylated sugars exploitable by bacterioplankton, such

434 as methylotrophs (McCarren et al., 2010), Methylophaga may have also participated here in the

435 recycling of phytoplankton-produced DOM. Furthermore, these enriched Methylophaga, represented

436 by OTU-9, may represent novel species since they share $\leq 97 \% 16 \mathrm{~S}$ rRNA gene sequence identity to

437 their closest relative, the type strain Methylophaga thiooxydans strain DMS010 ${ }^{\mathrm{T}}$ (Boden et al., 438 2010).

439 Other members that had become enriched by the oil relative to the untreated control (CON)

440 included members of the order BD7-3 (OTU-1), Rhodobacteraceae (OTU-3), Thalassospira (OTU- 
442 16), Olleya (OTU-17), Winogradskyella (OTU-18), Methylotenera (OTU-19) and Verrucomicrobium

443 (OTU-20). Based on a BLASTn analysis of their 16S rRNA sequences, except for Cycloclasticus

444 OUT-6, these organisms may represent novel species since they each shared $\leq 99 \%$ identity to closest 445 type strains; in the case of BD7-3 (OTU-1) and Verrucomicrobium (OTU-20), the highest sequence 446 match to a type strain was $88 \%$ and $91 \%$, respectively. Of these taxa, Thalassospira and Halomonas 447 contain members with reported hydrocarbon-degrading qualities (Zhao et al., 2010; Gutierrez et al., 448 2013a and references therein), and Oleispira is a genus comprising members of obligate

449 hydrocarbon-degraders with a preference for utilizing straight-chain aliphatics (Head et al., 2006;

450 Yakimov et al., 2007). The family Rodobacteraceae includes the Roseobacter clade, which is

451 commonly found in high abundance during algal blooms (González et al., 2000). Its enrichment in

452 the PHY incubations, albeit moderately greater than in the CON incubations, may be attributed to 453 these organisms encoding multiple ring-cleaving pathways that participate in the degradation of

454 monocyclic and PAHs (Moran et al., 2007). Notably, members of the order BD7-3, like the

455 Piscirickettsiaceae (incl. Methylophaga) and Colwelliaceae, were strongly enriched in the PHY

456 incubations amended with oil. Members of this order are inconspicuous by the very fact that they are 457 poorly represented in 16S rRNA gene databases and their distribution and ecology is practically 458 unknown. To the best of our knowledge, no reports have described any member of the BD7-3 to 459 degrade hydrocarbons, and our results provide the first evidence to suggest that these organisms 460 might encode this phenotype, or play an indirect role in hydrocarbon biodegradation. The

461 Flavobacteriaceae contain members with hydrocarbon-degrading qualities, including Arenibacter

462 which is a genus comprising members with the ability to degrade PAHs (Gutierrez et al., 2014).

463 Arenibacter associated with diatoms have been shown to become enriched by crude oil

464 (Mishamandani et al., 2015), and although members of Shewanella are not commonly associated 465 with oil spills, a hydrocarbon-degrading species of this genus has been described that originated from 466 Antarctic waters (Gentile et al., 2003). All the other taxa that were enriched by the oil (i.e. Olleya, 
467 Winogradskyella, Methylotenera, Verrucomicrobium) have, to the best of our knowledge, no

468 representatives that have been described to degrade hydrocarbons.

469 This study represents the first investigation on the response of a natural phytoplankton-

470 bacterial assemblage to crude oil with a focus in teasing apart and comparing the dynamic response

471 of the phytoplankton-associated bacterial community to that which is free-living, including a

472 paralleled analysis of the hydrocarbons degraded by these communities. Our findings show that the

473 associated bacterial community contributed an important role in the degradation of the more toxic

474 aromatic hydrocarbon components of crude oil. Following from our previous study where we

475 showed this preferential degradation of aromatic hydrocarbons in crude oil by the bacterial

476 community associated with the cosmopolitan marine diatom Skeletonema costatum (Mishamanadani

477 et al., 2015), our work highlights phytoplankton as a natural biotope in the ocean that harbour a

478 diversity of HCB. Our work has revealed the presence of novel taxa associated with marine

479 phytoplankton that respond upon exposure to oil, notably members of the order BD7-3,

480 Methylotenera and Verrucomicrobium, that may be putative hydrocarbon-degraders. The prominence

481 of HCB with phytoplankton could be described as a hallmark of phytoplankton, standing at the ready

482 as sentinels in the water column to respond and help purge the marine water column in the event of

483 petrochemical inputs. Considering the close interactions between phytoplankton and microbial

484 communities, and including the apparent ubiquitous representation of hydrocarbon-degraders to the

485 associated bacterial community (McGenity et al., 2012), future oil biodegradation and

486 bioremediation studies should therefore not ignore these associations.

488 Experimental Procedures

489 Field sample collection and crude oil enrichment set-up

490 Loch Creran is a $12.8 \mathrm{~km}$ long fjordic sea loch (1.3 km average width; $13.5 \mathrm{~m}$ average depth; $49 \mathrm{~m}$

491 max. depth) that is located on the west coast of Scotland and receives waters from the open sea.

492 During a sampling operation aboard $R V$ Serpula on 24 May 2013 to a sampling station in the lower 
493 basin of Loch Creran $\left(56^{\circ} 30.820 \mathrm{~N}, 5^{\circ} 22.817 \mathrm{~W}\right)$, we trawled a phytoplankton net $(50-60 \mu \mathrm{m}$ mesh

494 size) near the sea surface (1-2 m depth) for several minutes to collect the phytoplankton community;

495 we also collected ca. 10 litres of seawater into a pre-sterilized 10-L polypropylene carboy. The lower

496 basin of Loch Creran $\left(56^{\circ} 30.820 \mathrm{~N}, 5^{\circ} 22.817 \mathrm{~W}\right)$ was chosen here for investigating the response of

497 algal-bacterial communities to crude oil as it contains relatively high levels of phytoplankton for

498 western Scottish coastal waters (Tett and Edwards, 2002). The seawater and phytoplankton net

499 samples were passaged through a $125-\mu \mathrm{m}$ metal mesh filter to remove grazers, then stored at $4^{\circ} \mathrm{C}$ and

500 used within 24 hours for the preparation of the various experiments described below. Sub-samples

501 were sent to the Scottish Environmental Protection Agency (SEPA) for microscopic identification of

502 the phytoplankton taxa and their abundance in the collected samples.

In order to examine the microbial response and potential of phytoplankton-associated HCB

communities on the biodegradation of crude oil, two oil enrichment treatments, PHY and BAC, were

set up. Treatment PHY constituted the phytoplankton with its associated bacterial community from

the Loch Creran surface water sample. The inoculum for this treatment was prepared by adding 500

$\mathrm{mL}$ of the washed phytoplankton net trawl to $10 \mathrm{~L}$ of filtered $(0.2 \mu \mathrm{m})$ seawater. Treatment BAC

comprised solely the free-living bacterial fraction, the inoculum for which was prepared by passing

ca. $1 \mathrm{~L}$ of the Loch Creran water through $2-\mu \mathrm{m}$ (Isopore) filters to remove phytoplankton cells. Each

of the two treatments (PHY and BAC) was conducted in triplicate using autoclaved 1-L Erlenmeyer

511 flasks, which were filled with $350 \mathrm{ml}$ of the respective inoculum prepared as described above. To

512 each of the triplicate flasks for treatment PHY (designated P1, P2, P3) and for treatment BAC

513 (designated B1, B2, B3) were amended with $0.2 \mu \mathrm{m}$-sterilised Heidrun crude oil to a final oil slick

514 content of ca. $1 \%(\mathrm{v} / \mathrm{v})$ - an amount that has been used to simulate laboratory-controlled oil

515 enrichments (Piehler et al., 1999). Heidrun crude oil (Statoil) was sourced from the Norwegian

516 Sector of the North Sea and is classed as a light-to-medium density, low sulfur crude oil. Heidrun

517 crude oils can vary with respect to their composition, which largely depends on their extent of

518 weathering in the field from where they are sourced. Generally, they consist of approximately $46 \%$ 
519 naphthenes, 38\% aromatics, $15 \%$ paraffins and other compounds, with varying proportions of $n$ -

520 alkanes that can range from undetectable to low percent content of TPH since this fraction of

521 hydrocarbons is often the most susceptible to biodegradative processes (Karlsen et al., 1995). GC-

522 MS analysis of the Heidrun crude oil used in our study revealed it contained $\mathrm{C}_{8}-\mathrm{C}_{35} n$-alkanes that

523 collectively contributed ca. $4 \%$, with a higher proportion of aromatics at ca. $15 \%$ of TPH.

524 Ratios of $n$-alkanes to acyclic isoprenoid hydrocarbons $(n \mathrm{C} 17 /$ pristane and $n \mathrm{C} 18 /$ phytane)

525 were used as convenient indicators of biological degradation, due to the recalcitrance imparted by the

526 branched structure of the isoprenoid biomarkers (Sauer and Boehm, 1991; Papazova and Pavlova,

527 1999; Dawson et al., 2013). Similarly for aromatic hydrocarbon analysis, this was done for 7 ratios

528 indicative of biodegradation (naphthalene/2-methylnaphthalene; 2-methylnaphthalene/1-

529 methylnaphthalene; 2-ethylnaphthalene/2,6+2,7-dimethylnaphthalene; 2-methylnaphthalene/2,6+2,7-

530 dimethylnaphthalene; phenanthrene/9-methylphenanthrene; 3+2-methylphenanthrene/9+1-

531 methylphenanthrene; 3-methylphenanthrene/9-methylphenanthrene).

532 A third treatment (treatment $\mathrm{CON}$ ) was set up in the exact same way as treatment PHY, with

533 the exception that the oil was not added in order to serve as untreated controls (designated C1, C2,

$534 \mathrm{C} 3$ ). All nine flasks were incubated in a temperature-controlled $15^{\circ} \mathrm{C}$ illuminated incubator with a

$53512: 12$ light/dark cycle and at a photon flux density of ca. $100 \mu \mathrm{mol} \mathrm{s}^{-1} \mathrm{~m}^{-2}$. Samples for micro-algal

536 and bacterial counts were taken at days $0,2,5,8,11,14,24$ and 40. Samples for molecular analysis

537 were taken at days $0,8,14,24$ and 40 . Prior to sampling, the contents of each flask was stirred by a

538 magnetic stir bar that had been placed inside each flask at the time they had been autoclaved.

539 In order to analyze for changes in the composition of the oil due to biodegradation, an

540 additional six flasks were prepared in the same way as for treatment PHY. Of these six flasks, three

541 were treated with $85 \%$ phosphoric acid to a final concentration of $3 \%$ to serve as the acid-inhibited

542 controls. An additional six flasks were prepared in the same way as for treatment BAC, of which

543 three were treated in the same way with $85 \%$ phosphoric acid. All twelve flasks (six uninhibited and

544 six acid-treated) were incubated in parallel together with the flasks above in the temperature- 
545 controlled illuminated incubator. At the termination of the experiment (day 40), these twelve flasks

546 were extracted for total petroleum hydrocarbons (TPH) and subsequent analysis for individual

547 hydrocarbon constituents by gas chromatography/mass spectrometry (GC-MS), as detailed below.

549 Hydrocarbon analysis

$550 \quad$ Each flask was sacrificed at specified time points for extraction of TPH using

551 dichloromethane (DCM) at an oil/water mix to DCM ratio of 1:2. The DCM fraction was removed

552 and the oil/water mix re-extracted an additional 3 times. The extracted oil sample was then diluted

553 with DCM to ca. $5 \mathrm{ml}$ and dried by the addition of a small amount of anhydrous sodium sulphate. The

554 sample was removed from the sodium sulphate using a pipette. The sodium sulphate was washed 4

555 times with a small amount of DCM and the washings were combined with the dilute oil sample.

556 Sample volume was reduced to ca. $2-3 \mathrm{ml}$, transferred to a measuring cylinder and diluted to $5 \mathrm{ml}$. An

557 aliquot of known volume was removed, evaporated to dryness and weighed. The gravimetric data

558 were used to calculate the original sample weight and the weight of oil remaining.

A known aliquot corresponding to ca. 30mg was taken from the remaining sample and

560 transferred to a $10 \mathrm{ml}$ vial. An aliquot of the reference oil was weighed directly into a vial and diluted

561 with ca. $0.3 \mathrm{ml}$ DCM. Squalane and 1,1'-binaphthyl were added as surrogate standards at ca. $0.5 \%$

562 and $0.05 \%$ by weight of the oil, respectively. A procedural blank including the standards was also

563 prepared. One sample was analysed in triplicate and the reference oil was analysed in duplicate.

A chromatographic column was prepared using silica topped with alumina. Both sorbents

565 were pre-extracted with DCM and activated at $120^{\circ} \mathrm{C}$ prior to use. The sorbents were introduced as

566 slurries in petroleum ether (b.p. range $40-60^{\circ} \mathrm{C}$ ). The sample (sorbed to $\sim 3 \mathrm{~g}$ alumina) was applied to

567 the top of the column. The total hydrocarbon (TPH) fraction was eluted with $50 \mathrm{ml}$ petroleum ether

568 followed by $70 \mathrm{ml}$ petroleum ether/DCM (2:5). Solvent was reduced to ca. $2 \mathrm{ml}$ using a Heidolph

569 rotary evaporator. The sample was transferred to a vial and diluted to $3.4 \mathrm{ml}$, and an aliquot was

570 removed for gas chromatographic analysis. 
572 injector $\left(300^{\circ} \mathrm{C}\right)$, a flame ionisation detector (FID) $\left(310^{\circ} \mathrm{C}\right)$ and an HP-5 capillary column (J\&W, $57330 \mathrm{~m} \times 0.25 \mathrm{~mm}$ i.d. x $0.25 \mu \mathrm{m}$ film thickness). Samples were injected using a Hewlett Packard 6890 574 automatic injector. The oven programme was $50^{\circ} \mathrm{C}(2 \mathrm{~min})-5^{\circ} \mathrm{C} / \mathrm{min}-300^{\circ} \mathrm{C}(20 \mathrm{~min})$ giving a 575 total run time of 74 min. Chromatographic data were acquired and processed using an Atlas 8.3 576 Chromatographic Data System (Thermo Scientific). Peak areas for individual $\mathrm{C}_{8}$ to $\mathrm{C}_{35} n$-alkanes, 577 the isoprenoids pristane and phytane, and for the surrogate standard squalane were obtained. The 578 total hydrocarbon content was calculated using the manually integrated area under the whole 579 chromatogram, drawing a horizontal baseline from the start of the solvent peak to the end of the 580 acquisition. The corresponding total area for the procedural blank (which also contained the 581 surrogate standards) was then subtracted from the total area obtained for the samples and reference 582 oil. Analyte concentrations were measured using the areas of the added standards, assuming a 583 response factor of one. The aromatic hydrocarbons in the TPH fractions were analysed by GC-MS on an Agilent $7890 \mathrm{~A} \mathrm{GC}$ fitted with a split/split less injector (at $280^{\circ} \mathrm{C}$ ) linked to an Agilent $5975 \mathrm{C}$

585 MSD, with data acquisition and processing by Agilent Chemstation software. Selected samples were 586 analysed in full scan mode (50-600 amu/sec) but all samples were analysed in selected ion 587 monitoring (SIM) mode using the analyte aromatic hydrocarbon molecular ions or major fragment 588 ions. An aliquot $(1 \mu \mathrm{l})$ of the TPH fraction diluted in hexane/dichloromethane was injected in 589 split/splitless mode using an Agilent 7683B autosampler and the split opened after 1 minute.

590 Separation was performed on an Agilent fused silica capillary column (30 m x $0.25 \mathrm{~mm}$ i.d) coated 591 with $0.25 \mu \mathrm{m} 5 \%$ phenylmethylpolysiloxane (HP-5) phase. The GC was temperature programmed 592 from $50-310^{\circ} \mathrm{C}$ at $5{ }^{\circ} \mathrm{C}$ min and held at final temperature for 10 minutes with helium as the carrier 593 gas (flow rate of $1 \mathrm{ml} / \mathrm{min}$, initial inlet pressure of $50 \mathrm{kPa}$, split at $30 \mathrm{ml} / \mathrm{min}$ ). Individual aromatic 594 hydrocarbon analytes were semi-quantitatively determined by comparison of their peak areas in their 595 respective ion chromatograms with that of the added 1,1'-binaphthyl standard ( $\mathrm{m} / \mathrm{z} 253)$ assuming a 596 response factor of one. 
598 after 40 days were calculated by subtracting the respective hydrocarbon concentrations measured in

599 the acidified controls from those of the non-acidified incubations. A Student's $t$-test was performed

600 to test for significant differences $(P<0.05)$ in the degradation of the hydrocarbons analysed between

601 the treatments.

602

603 Extraction of DNA

604 Cell biomass from samples $(5 \mathrm{ml})$ taken at each sampling point from treatments PHY, BAC and

605 CON was collected by filtration using a glass vacuum filtration system (Millipore) with $25 \mathrm{~mm}$

606 polycarbonate membrane filters $(0.2 \mu \mathrm{m}$ pore size; Isopore $)$ and the filters stored at $-20^{\circ} \mathrm{C}$. The

607 polycarbonate membranes were placed into $1.5 \mathrm{ml}$ Eppendorf tubes containing $200 \mu \mathrm{l}$ reaction buffer

608 (10mM Tris; $1 \mathrm{mM}$ EDTA; $0.5 \%$ (w/v) SDS; $50 \mu \mathrm{g} \mathrm{ml}^{-1}$ proteinase K). Tubes were gently vortexed

609 and incubated for 30 minutes at room temperature. Filters were then dissolved with the addition of

$610200 \mu \mathrm{l}$ of $\mathrm{pH} 8$ equilibrated phenol:chloroform:isoamyl alcohol (25:24:1) for 5 minutes. Reactions

611 were centrifuged $(10,000 \mathrm{rpm} ; 5 \mathrm{~min})$ and DNA in the aqueous top phase was transferred to a clean

612 tube. TE $(200 \mu \mathrm{l})$ was added to the original tube and centrifuged a second time to capture the

613 remaining nucleic acid. The aqueous phases were combined and nucleic acid was precipitated with

$61410 \% \mathrm{NaCl}$ and $2.5 \mathrm{x}$ volumes of $i s o$-propanol for 30 minutes on ice. The DNA was recovered by

615 centrifugation $(17,000 \mathrm{rpm} ; 10 \mathrm{~min})$, washed with $70 \%$ ethanol, dried and then resuspended in $50 \mu \mathrm{l}$

616 of TE buffer. Purified DNA was stored at $-20^{\circ} \mathrm{C}$ for subsequent quantification and molecular

617 analysis. For quantitation of DNA, a NanoDrop ND-3300 fluorospectrometer (Labtech, East Sussex,

618 UK) and the Quant-iT Picogreen double-stranded DNA (dsDNA) kit (Invitrogen, Carlsbad, CA,

619 USA) were used.

620

621 Quantification of the bacterial population and phytoplankton by real-time PCR and Chl a

622 measurements 
623 Samples $(2 \mathrm{ml})$ for Chl $a$ determinations were extracted using a modified version of EPA Method

624445 (Arar and Collins, 1997). For this, each 2-ml sample was filtered through a $25 \mathrm{~mm}$ Glass Fiber

625 Filter (GF/F) and then placed into $10 \mathrm{ml}$ of $90 \%$ acetone. Samples were sonicated in an ice water

626 bath for $10 \mathrm{~min}$ in the dark and then maintained at $-20^{\circ} \mathrm{C}$ for ca. 20 hours. The samples were then

627 centrifuged and the supernatant fractions transferred to clean tubes and allowed to equilibrate in the

628 dark at room temperature prior to fluorometric analysis on a Turner Trilogy Fluorometer (Turner

629 Designs, CA 94085) using an excitation wavelength of $485 \mathrm{~nm}$ and emission of $685 \mathrm{~nm}$. Chl $a$

630 concentrations were calculated from a standard curve constructed from serial dilutions of a Chl $a$

631 extract (Turner Designs, CA 94085) as per the method of Welshemeyer (1994).

632 To quantify the prokaryotic (bacteria and archaea) response to crude oil, we initially used the

633 DAPI (4'6-diamidino-2-phenylindole) staining technique. However, this was not pursued further

634 because we observed clusters of prokaryotic cells attached to live and dead/dying phytoplankton

635 cells, including aggregates of these, which made it impossible to provide an accurate measure of

636 prokaryotic cell counts. We therefore decided to focus on the bacterial community since to-date no

637 archaeal representative has been identified with the ability to degrade hydrocarbons. For this, we

638 quantified the abundance of bacterial 16S rRNA genes, as a proxy for bacterial biomass, by real-time

639 quantitative PCR (qPCR) using bacterial primers 341f (Muyzer et al., 1993) and 518r (Øvreås et al.,

640 1997). Single reactions were performed on each triplicate DNA extraction from triplicate samples

641 collected at each sampling time point. The template for the construction of the respective standard

642 curve for qPCR was a PCR amplicon of E. coli $16 \mathrm{~S}$ rRNA gene that was amplified with $E$. coli

643 primers ECP79f (5'-GAAGCTTGCTTCTTTGCT-3') and ECR620r (5'-

644 GAGCCCGGGGATTTCACA-3'). An annealing temperature of $55^{\circ} \mathrm{C}$ was used for the qPCR

645 programme employing these primers.

646

647 Barcoded amplicon metagenomic sequencing and analysis 
648 Barcoded 16S rRNA gene MiSeq was used to analyse the bacterial community in the purified DNA 649 extracts from samples collected at days 0 (prior to oil amendment), 8,14 and 40. Almost full length 650 16S rRNA sequences were amplified using the 27f (Wilmotte et al., 1993) and 1492r (Lane, 1991) 651 primers $(20 \mu \mathrm{M})$ in $50 \mu \mathrm{l}$ reactions containing $45 \mu \mathrm{l}$ Supermix (IDT Invitrogen) and $1 \mu 1$ of nucleic 652 acid extract. We performed an initial extension of 1 minute at $94{ }^{\circ} \mathrm{C}$ followed by 35 PCR cycles $(45$ 653 seconds at $94{ }^{\circ} \mathrm{C} ; 45$ seconds at $45{ }^{\circ} \mathrm{C} ; 1$ minute at $72{ }^{\circ} \mathrm{C}$ ) and a final denaturation stage of 5 minutes 654 at $72{ }^{\circ} \mathrm{C}$. PCR products were then cleaned by addition of $5 \mu \mathrm{FastAP}\left(1 \mathrm{U} \mu \mathrm{l}^{-1}\right)$ and $7.5 \mu \mathrm{l}$ 655 Exonuclease I $\left(1 \mathrm{U} \mu \mathrm{l}^{-1}\right)$ (Life Technologies) $\left(45\right.$ minutes at $37^{\circ} \mathrm{C} ; 15$ minutes at $\left.85^{\circ} \mathrm{C}\right)$. A second 656 round of PCR targeting the hypervariable V3 and V4 regions was performed using MiSeq forward 657 (5' AATGATACGGCGACCACCGAGATCTACAC $<8$-nt i5 barcode $>$ TATGGTAATT GT 658 ACWCCTRCGGGWGGCWG3') and reverse (5'-CAAGCAGAAGACGGCATACGAGAT <8-nt i7 barcode> AGTCAGTCAG CC ACCAGGGTATCTAAKCCTG 3') primers (20 $\mu \mathrm{M})$. Primers were 660 added to a tube containing $5 \mu$ of cleaned PCR product, MyTaq polymerase ( $5 \mathrm{U}$ ), MyTaq reaction 661 buffer (1x) and DMSO (1.5\%) (total of $20 \mu \mathrm{l}$ reaction). For this round we performed an initial 662 extension of 3 minutes at $95{ }^{\circ} \mathrm{C}$ followed by 28 PCR cycles $\left(15\right.$ seconds at $95{ }^{\circ} \mathrm{C} ; 15$ seconds at 55 $663{ }^{\circ} \mathrm{C} ; 1$ minute at $72{ }^{\circ} \mathrm{C}$ ) and a final denaturation stage of 5 minutes at $72{ }^{\circ} \mathrm{C}$. Once again the PCR 664 product was cleaned by addition of $2 \mu$ FastAP $\left(1 \mathrm{U} \mathrm{L}^{-1}\right)$ and $3 \mu$ Exonuclease $\mathrm{I}\left(1 \mathrm{U} \mathrm{L}^{-1}\right)(45$ minutes 665 at $37^{\circ} \mathrm{C} ; 15$ minutes at $85^{\circ} \mathrm{C}$ ). The expected length of the amplicon after the second round was 666450 mer.

667 Samples were sequenced via the Illumina MiSeq platform at the University of Liverpool 668 Centre for Genomic Research where a final 8 cycles of PCR were performed with Illumina Nextera 669 XT forward and reverse primers containing a compatible adapter and a 2 bp linker sequence. Raw 670 Illumina fastq forward and reverse files were merged via Pandaseq and sequences smaller than 400 671 mer were trimmed using Prinseq ( $~ 80 \%$ of sequences were conserved), producing a total of $6723,140,774$ reads. QIIME software was used to cluster the sequences into operational taxonomic units 673 (OTUs) at 97\% similarity. Representative sequences were blasted and the GreenGenes database was 
674 used to assign taxonomy to the representative strain/OTU cluster. Data were normalised by

675 expressing the number of sequences in each OTU cluster as a percentage of total sequences for each

676 sample library. Chloroplast sequences were deleted and percentage abundances of bacterial 16S

677 rRNA gene sequences were adjusted accordingly. Representative OTUs of unknown phylogenetic

678 classification were checked for known sequences using RDP and BLASTn. A heatmap was produced

679 manually using Microsoft Excel to show all OTUs, with a relative abundance of $>1 \%$, that had

680 become enriched in the Heidrun crude oil incubations. Sequence data were submitted to MG-RAST

681 under ID number mgm4742856.3.

682

683 Phylogenetic tree

684 Representative 16S rRNA gene sequences of OTUs representing putative and recognized members

685 of hydrocarbon degrading taxa identified by MiSeq analysis were aligned using CLUSTAL_X

686 programme (Thompson et al., 1994). Sequences and type strains with the highest sequence similarity

687 from GenBank were also used for tree construction. A neighbour-joining tree was constructed with

688 TREEVIEW (WIN32) version 1.5.2 (Page, 1996) and bootstrap replication ( $\mathrm{n}=1000)$, and

689 Methanobacterium aarhusense (AY386124), Methanobacterium flexile (NR116276) and

690 Methanobacterium paludis (NR133895) were used as the outgroup.

691

692 Nucleotide sequence accession numbers

693 GenBank accession numbers for the representative OTUs that were identified as enriched by crude

694 oil are as follows: BD7-3 OTU-1 (KY962625), Hyphomonadaceae OTU-2 (KY962626),

695 Rhodobacteraceae OTU-3 (KY962627), Thalassospira OTU-4 (KY962628), Phaeobacter OTU-5

696 (KY962629), Cycloclasticus OTU-6 (KY962630), Colwelliaceae OTU-7 (KY962631),

697 Piscirickettsiaceae OTU-8 (KY962632), Methylophaga OTU-9 (KY962633), Oleispira OTU-10

698 (KY962634), Marinomonas OTU-11 (KY962635), Alcanivorax OTU-12 (KY962636), Halomonas

699 OTU-13 (KY962637), Shewanella OTU-14 (KY962638), Psychromonas OTU-15 (KY962639), 


\section{Acknowledgements}

704 We would like to thank the captain Colin Moore and his crew of $R V$ Serpula for their support on the 705 cruise to Loch Creran and for accommodating all of our research needs. This work was supported by 706 a James-Watt Postgraduate Scholarship to H.F.T. and a Royal Society Research Grant (RG140180) 707 to T.G. We also thank M. Baptise of the Scottish Environmental Protection Agency (SEPA) for 708 providing data on the diversity and abundance of phytoplankton species in the Loch Creran seawater 709 sample used in this study, as well as R. Shields for providing us with the Heidrun crude oil, and K.

710 Salek for assistance with the crude oil extraction. We would also like to thank the three anonymous 711 reviewers for their valuable comments during the preparation of the manuscript. The authors declare 712 no conflict of interest.

\section{References}

715 1. Abed, R.M.M., and Köster, J. (2005) The direct role of aerobic heterotrophic bacteria associated 716 with cyanobacteria in the degradation of oil compounds. Int Biodeterior Biodegrad 55: 29-37.

717 2. Adekunle, I.M., Ajijo, M.R., Adcofun, C.O., and Omoniyi, I.T. (2010) Response of four 718 phytoplankton species found in some sectors of Nigerian coastal waters to crude oil in controlled $719 \quad$ ecosystem. Int J Environ Res 4: 65-74.

720 3. Agency for Toxic Substances and Disease Registry (2007) CERCLA priority list of hazardous substances. Agency for Toxic Substances and Disease Registry, Atlanta, GA. http://www.atsdr.cdc.gov/cercla/07list.html

723 4. Alldredge, A.L., Passow, U., and Logan, B.E. (1993) The abundance and significance of a class 724 of large, transparent organic particles in the ocean. Deep-Sea Res Part I 40: 1131-1140. 
725 5. Amin, S.A., Green, D.H., Hart, M.C., Kupper, F.C., Sunda, W.G., and Carrano, C.J. (2009) Photolysis of iron-siderophore chelates promotes bacterial-algal mutualism. Proc Natl Acad Sci USA 106: 17071-17076.

6. Amin, S.A., Hmelo, L.R., van Tol, H.M., Durham, B.P., Carlson, L.T., Heal, K.R., et al. (2015) Interactions and signalling between a cosmopolitan phytoplankton and associated bacteria. Nat 522: $98-101$.

7. Amin, S.A., Parker, M.S., and Ambrust, E.V. (2012) Interactions between diatoms and bacteria. Microbiol Mol Biol Rev 76: 667-684.

8. Andelman, J.B., and Suess, M.J. (1970) Polynuclear aromatic hydrocarbons in the water environment. Bull World Health Organ 43: 479-508.

9. Arar, E.J., and Collins, G.B. (1997) Method 445: In vitro determination of chlorophyll a and pheophytin a in marine and freshwater algae by Fluorescence, Cincinnati, Ohio, U. S. Environmental Protection Agency.

10. Arnosti, C., Ziervogel, K., Yang, T., and Teske, A. (2015) Oil-derived marine aggregates - hot spots of polysaccharide degradation by specialized bacterial communities. Deep-Sea Res Part II 129: $179-186$.

11. Bælum, J., Borglin, S., Chakraborty, R., Fortney, J.L., Lamendella, R., Mason, O.U., et al. (2012) Deep-sea bacteria enriched by oil and dispersant from the Deepwater Horizon spill. Environ. Microbiol 14: 2405-2416.

12. Bailey, N., Bailey, D.M., Bellini, L.C., Fernandes, P.G., Fox, C., Heymans, et al. (2011) The west of Scotland marine ecosystem: a review of scientific knowledge. Marine Scotland Science Report 09/11.

13. Barakat, A.O., Qian, Y., Kim, M., and Kennicutt Ii, M.C. (2002) Compositional changes of aromatic steroid hydrocarbons in naturally weathered oil residues in the Egyptian western desert. Environ Forensics 3: 219-225.

14. Bate, G., and Crafford, S.D. (1985) Inhibition of phytoplankton photosynthesis by the WSF of 
used lubricating oil. Mar Pollut Bull 16: 401-404.

752 15. Bell, W., and Mitchell, R. (1972) Chemotactic and growth responses of marine bacteria to algal extracellular products. Biol Bull 143: 265-277.

754 16. Boden, R., Kelly, D.P., Murrell, J.C., and Schäfer, H. (2010) Oxidation of dimethylsulfide to tetrathionate by Methylophaga thiooxidans sp. nov.: a new link in the sulfur cycle. Environ Microbiol 12: 2688-2699.

17. Boehm, P.D., and Page, D.S. (2007) Exposure elements in oil spill risk and natural resource damage assessments: a review. Hum Ecol Risk Assess 13: 418-448.

18. Borde, X., Guieysse, B., Delgado, O., Muñoz, R., Hatti-Kaul, R., Nugier- Chauvin, C., et al. (2003) Synergistic relationships in algal-bacterial microcosms for the treatment of aromatic pollutants. Biores Technol 86: 293-300.

19. Buchan, A., LeCleir, G.R., Gulvik, C.A., and González, J.M. (2014) Master recyclers: features and functions of bacteria associated with phytoplankton blooms. Nat Rev Microbiol 12: 686698.

20. Castberg, T., Larsen, A., Sandaa, R.A., Brussaard, C.P.D., Egge, J.K., Heldal, M., et al. (2001) Microbial population dynamics and diversity during a bloom of the marine coccolithophorid Emiliania huxleyi (Haptophyta). Mar Ecol Prog Ser 221: 39-46.

21. Chang, F.H., Zeldis, J., Gall, M., and Hall, J. (2003) Seasonal and spatial variation of phytoplankton assemblages, biomass and cell size from spring to summer across the northeastern New Zealand continental shelf. J Plankton Res 25: 737-758.

22. Coulon, F., McKew, B.A., Osborn, A.M., McGenity, T.J., and Timmis, K.N. (2007). Effects of temperature and biostimulation on oil-degrading microbial communities in temperate estuarine waters. Environ Microbiol 9: 177-186.

23. Dawson, K.S., Schaperdoth, I., Freeman, K.H., and Macalady, J.L. (2013) Anaerobic biodegradation of the isoprenoid biomarkers pristane and phytane. Organic Geochem 65: 118126. 
24. Diercks, A-R., Highsmith, R.C., Asper, V.L., Joung, D.J., Zhou, Z., Guo, L., et al. (2010) Characterization of subsurface polycyclic aromatic hydrocarbons at the Deepwater Horizon wellhead site. Geophys Res Lett 37: L20602.

25. Díez, S., Sabatté, J., Viñas, M., Bayona, J.M., Solanas, A.M., Albaigés, J. (2005) The prestige oil spill. I. Biodegradation of a heavy fuel oil under simulated conditions. Environ Toxicol Chem

26. Dong, C., Bai, X., Lai, Q., Xie, Y., Chen, X., Shao, Z. (2014) Draft genome sequence of Marinomonas sp. strain D104, a polycyclic aromatic hydrocarbon-degrading bacterium from

27. D’souza, N.A., Subramaniam, A., Juhl, A.R., Hafez, M., Chekalyuk, A., Phan, S., et al. (2016) the deep-sea sediment of the Arctic Ocean. Genome Announc 2: e1211-13. Elevated surface chlorophyll associated with natural oil seeps in the Gulf of Mexico. Nat Geosci

32. Field, C.B., Behrenfield, M.J., Randerson, J.T., and Falkowski, P. (1998) Primary production of 9: $215-218$.

28. Ducklow, H.W., Steinberg, D.K., and Buesseler, K.O. (2001) Upper ocean carbon export and the biological pump. Oceanogr 14: 50-58.

29. Dunstan, W., Atkinson, L., and Natoli, J. (1975) Stimulation and inhibition of phytoplankton growth by low molecular weight hydrocarbons. Mar Biol 31: 305-310.

30. Exton, D.A., Steinke, M., Suggett, D.J., and McGenity, T.J. (2012) Spatial and temporal variability of biogenic isoprene emissions from a temperate estuary. Global Biogeochem Cycl 26: GB2012, doi:10.1029/2011GB004219.

31. Fehling, J., Davidson, K., Bolch, C., and Tett, P. (2006) Seasonality of Pseudo-nitzschia spp. (Bacillariophyceae) in western Scottish waters. Mar Ecol Progr Ser 323: 91-105.
the biosphere: integrating terrestrial oceanic components. Sci 281: 237-240.

33. Fu, J., Gong, Y., Zhao, X., O’Reilly, S.E., and Zhao, D. (2014) Effects of oil and dispersant on formation of marine oil snow and transport of oil hydrocarbons. Environ Sci Technol 48: 1439214399. 
803 34. Gentile, G., Bonasera, V., Amico, C., Giuliano, L., and Yakimov, M.M. (2003) Shewanella sp.

804 GA-22, a psychrophilic hydrocarbonoclastic Antarctic bacterium producing polyunsaturated 805 fatty acids. J Appl Microbiol 95: 1124-1133.

806 35. Gilde K, and Pinckney JL. (2012) Sublethal effects of crude oil on the community structure of $807 \quad$ estuarine phytoplankton. Estuar Coasts 35: 853-861.

808 36. González J, Fernandez E, Figueiras F, and Varela M. (2013) Subtle effects of the water 809 accommodated fraction of oil spills on natural phytoplankton assemblages enclosed in $810 \quad$ mesocosms. Estuar Coastal and Shelf Sci 124: 13-23.

811 37. González, J., Figueiras, F.G., Aranguren-Gassis, M., Crespo, B.G., Fernández, E., Morán, 812 X.A.G., et al. (2009) Effect of a simulated oil spill on natural assemblages of marine 813 phytoplankton enclosed in microcosms. Estuar Coastal and Shelf Sci 83: 265-276.

814 38. González, J.M., Simó, R., Massana, R., Covert, J.S., Casamayor, E.O., Pedrós-Alió, C., et al. 815 (2000) Bacterial community structure associated with a dimethylsulfoniopropionate-producing $816 \quad$ North Atlantic algal bloom. Appl Environ Microbiol 66: 4237-4246.

817 39. Green, D.H., Bowman, J.P., Smith, E.A., Gutierrez, T., and Bolch, C.J.S. (2006) Marinobacter 818 algicola $\mathrm{sp}$. nov., isolated from laboratory cultures of paralytic shellfish toxin-producing 819 dinoflagellates. Int J Syst Evol Microbiol 56: 523-527.

820 40. Green, D.H., Llewellyn, L.E., Negri, A.P., Blackburn, S.I., and Bolch, C.J.S. (2004)

821 Phylogenetic and functional diversity of the cultivable bacterial community associated with the 822 paralytic shellfish poisoning dinoflagellate Gymnodinium catenatum. FEMS Microbiol Ecol 47: $823 \quad 345-357$.

824 41. Gunnison, D., and Alexander, M. (1975) Basis for the resistance of several algae to microbial 825 decomposition. Appl Microbiol 29: 729-738.

826 42. Gutierrez, T., Berry, D., Yang, T., Mishamandani, S., McKay, L., Teske, A., et al. (2013a) Role 827 of bacterial exopolysaccharides (EPS) in the fate of the oil released during the Deepwater $828 \quad$ Horizon oil spill. PLoS ONE, doi: 10.1371/journal.pone.0067717. 
829 43. Gutierrez, T., Green, D.H., Nichols, P.D., Whitman, W.B., Semple, K.T., and Aitken, M.D.

830 (2012a) Algiphilus aromaticivorans gen. nov., sp. nov., an aromatic hydrocarbon-degrading

831 bacterium isolated from a culture of the marine dinoflagellate Lingulodinium polyedrum, and

832 proposal of Algiphilaceae fam. nov. Int J Syst Evol Microbiol 62: 2743-2749.

833 44. Gutierrez, T., Nichols, P.D., Whitman, W.B., and Aitken, M.D. (2012b) Porticoccus

834 hydrocarbonoclasticus sp. nov., an aromatic hydrocarbon-degrading bacterium identified in

835 laboratory cultures of marine phytoplankton. Appl Environ Microbiol 78: 628-637.

836 45. Gutierrez, T., Rhodes, G., Mishamandani, S., Berry, D., Whitman, W.B., Nichols, P.D., et al.

837 (2014) PAH degradation of phytoplankton-associated Arenibacter and description of

838 Arenibacter algicola sp. nov., an aromatic hydrocarbon-degrading bacterium. Appl Environ

$839 \quad$ Microbiol 80: 618-628.

840 46. Gutierrez, T., Singleton, D.R., Berry, D., Yang, T., Aitken, M.D., and Teske, A. (2013c)

$841 \quad$ Hydrocarbon-degrading bacteria enriched by the Deepwater Horizon oil spill identified by

$842 \quad$ cultivation and DNA-SIP. The ISME J 7: 2091-2104.

843 47. Harrison, P.J., Cochlan, W.P., Acreman, J.C., Parsons, T.R., Thompson, P.A., and Dovey, H.M.

844 (1986) The effects of crude oil and Corexit 9527 on marine phytoplankton in an experimental

845 enclosure. Mar Environ Res 18: 93-109.

846 48. Hazen, T.C., Dubinsky, E.A., DeSantis, T.Z., Andersen, G.L., Piceno, Y.M., Singh, N. et al.

847 (2010) Deep-sea oil plume enriches indigenous oil-degrading bacteria. Sci 330: 204-208.

848 49. Head, I.M., Martin Jones, D., and Röling, W.F.M. (2006) Marine microorganisms make a meal

$849 \quad$ of oil. Nat 4: 173-182.

850 50. Huang, Y.-J., Jiang, Z.-B., Zeng, J.-N., Chen, Q.-Z., Zhao, Y.-Q., Liao, Y.-B., et al. (2011) The

851 chronic effects of oil pollution on marine phytoplankton in a subtropical bay, China. Environ

$852 \quad$ Monitor Assess 176: 517-530.

853 51. Janvier, M., and Grimont, P.A.D. (1995). The genus Methylophaga, a new line of descent within $854 \quad$ phylogenetic branch $\gamma$ of Proteobacteria. Res Microbiol 146: 543-550. 
855 52. Jung, S.W., Kwon, O.Y., Joo, C.K., Kang, J.-H., Kim, K., Shim, W.J., et al. (2012) Stronger

856 impact of dispersant plus crude oil on natural plankton assemblages in short-term marine 857 mesocosms. J Haz Mater 217: 338-349.

858 53. Karlsen, D.A., Nyland, B., Flood, B., Ohm, S.E., Brekke, T., Olsen, S., et al. (1995) Petroleum 859 geochemistry of the Haltenbanken, Norwegian continental shelf. In Cubitt, J.M., England, W.A. 860 (Eds.), The Geochemistry of Reservoirs, Vol. 86. Geological Society Special Publication, $861 \quad$ London, pp. 203-256.

862 54. Karydis, M. (1981) The toxicity of crude oil for the marine alga Skeletonema costatum

863 (Greville) Cleve in relation to nutrient limitation. Hydrobiologia 85: 137-143.

864 55. Kazamia, E., Czesnick, H., Van Nguyen, T.T., Croft, M.T., Sherwood, E., Sasso, S., et al. 865 (2012) Mutualistic interactions between vitamin B12-dependent algae and heterotrophic bacteria 866

867 56. Kustenko, N.G. (1981) Effect of low oil concentrations on spermatogonangia and auxospores in 868 three marine diatom species. Oceanology 21: 263-265.

869 57. Lane, D.J. (1991) 16S/23S rRNA sequencing. In: Stackerbrandt, E. and Goodfellow, M. (eds.) $870 \quad$ Nucleic acid sequencing techniques in bacterial systematics. New York, NY: John Wiley \& 871 872

58. Lappalainen, M., and Tett, P. (2014) Creran microplankton 1979-81 and 2010-12. SAMS Progr Ser 312: 57-65.

60. Mallet, L., and Sardou, J. (1964) Examination of the presence of the polybenzic hydrocarbon benzo-3, 4-pyrene in the plank- tonic environment of the Bay of Villefranche. Symposium, committee on international scientific exploration of the mediterranean sea, Monaco. $C R A c a d$ $880 \quad$ Sci (Paris) 258: 5264-5267. 
881 61. Marlowe, I.T., Green, J.C., Neal, A.C., Brassell, S.C., Eglinton, G., and Course, P.A. (1984)

882 Long chain (n-C37- C39) alkenones in the Prymnesiophyceae. Distribution of alkenones and

$883 \quad$ other lipids and their taxonomic significance. Br Phycol J 19: 203-216.

884 62. McCarren, J., Becker, J.W., Repeta, D.J., Shi, Y., Young, C.R., Malmstrom, R.R., et al. (2010)

885 Microbial community transcriptomes reveal microbes and metabolic pathways associated with

886 dissolved organic matter turnover in the sea. Proc Natl Acad Sci USA 107: 16420-16427.

887 63. McGenity, T.J., Folwell, B.D., McKew, B.A., and Sanni, G.O. (2012) Marine crude-oil

888 biodegradation: a central role for interspecies interactions. Aquatic Biosystems 8: 10

889 doi:10.1186/2046-9063-8-10

890 64. McQuatters-Gollop, A., Raitsos, D.E., Edwards, M., and Attrill, M.J. (2007) Spatial patterns of 891 diatom and dinoflagellate seasonal cycles in the NE Atlantic Ocean. Mar Ecol Progr Ser 339: $892 \quad 301-306$.

893 65. Melcher, R.J., Apitz, S.E., and Hemmingsen, B.B. (2002) Impact of irradiation and polycyclic 894 aromatic hydrocarbon spiking on microbial populations in marine sediment for future aging and $895 \quad$ biodegradability studies. Appl Environ Microbiol 68: 2858-2868.

896 66. Mishamandani, S., Gutierrez, T., and Aitken, M.D. (2014) DNA-based stable isotope probing 897 898 coupled with cultivation methods implicates Methylophaga in hydrocarbon degradation. Front

68. Moore, C.G., Saunders, G.R., and Harries, D. (1998) The status and ecology of reefs of Serpula vermicularis L. (Polychaeta: Serpulidae) in Scotland. Aquatic Conservation: Mar Freshwater Ecosyst 8: 645-656.

905 69. Moran, M.A., Belas, R., Schell, M.A., Gonzalez, J.M., Sun, F., Sun, S., et al. (2007) Ecological 906 genomics of marine roseobacters. Appl Environ Microbiol 73: 4559-4569. 
907 70. Muñoz, R., Guieysse, B., and Mattiasson, B. (2003) Phenanthrene biodegradation by an algal908 bacterial consortium in two-phase partitioning bioreactors. Appl Microbiol Biotechnol 61: 261909267.

910 71. Muyzer, G., Dewaal, E.C., and Uitterlinden, A.G. (1993) Profiling of complex microbial

911 populations by denaturing gradient gel electrophoresis analysis of polymerase chain reaction-

912 amplified genes coding for 16s rRNA. Appl Environ Microbiol 59: 695-700.

913 72. Myklestad, S.M. (1995) Release of extracellular products by phytoplankton with special $914 \quad$ emphasis on polysaccharides. Sci Total Environ 165: 155-164.

915 73. Needham, D.M., and Fuhrman, J.A. (2016) Pronounced daily succession of phytoplankton, 916 archaea and bacteria following a spring bloom. Nat Microbiol 1: 16005, doi:

$917 \quad 10.1038 /$ NMICROBIOL.2016.5

918 74. Nomura, H., Toyoda, K., Yamada, M., Okamoto, K., Wada, M., Nishimura, M., et al. (2007)

919 Mesocosm studies on phytoplankton community succession after inputs of the water-soluble $920 \quad$ fraction of Bunker A oil. La Mer 45: 105-116.

921 75. Orsi, W.D., Smith, J.M., Wilcox, H.M., Swalwell, J.E., Carini, P., Worden, A.Z., et al. (2015) 922 Ecophysiology of uncultivated marine euryarchaea is linked to particulate organic matter. The 923 ISME J 9: 1747-1763.

924 76. Ostgaard, K., Eide, I., and Jensen, A. (1984a) Exposure of phytoplankton to Ekofisk crude oil. Mar Environ Res 11: 183-200.

926 77. Ostgaard, K., Hegseth, E. N., and Jensen, A. (1984b) Species-dependent sensitivity of marin planktonic algae to Ekofisk crude oil under different light conditions. Botanica Marina 27: 309-

929 78. Øvreås, L., Forney, L., Daae, F.L., and Torsvik, V. (1997) Distribution of bacterioplankton in 930 meromictic Lake Sælenvannet, as determined by denaturing gradient gel electrophoresis of 931 PCR-amplified gene fragments coding for 16S rRNA. Appl Environ Microbiol 63: 3367-3373. 932 79. Ozhan, K., and Bargu, S. (2014a) Distinct responses of Gulf of Mexico phytoplankton 
communities to crude oil and the dispersant Corexit ${ }^{\circledR}$ EC9500A under different nutrient regimes. Ecotoxicol 23: 370-384.

935 80. Ozhan, K., and Bargu, S. (2014b) Responses of sympatric Karenia brevis, Prococentrum 936 minimum, and Heterosigma akashiwo to exposure of crude oil. Ecotoxicol 23: 1387-1398.

937 81. Ozhan, K., Parsons, M.L., and Bargu, S. (2014) How were phytoplankton affected by the 938 Deepwater Horizon oil spill? BioSci 64: 829-836.

939 82. Page, R.D.M. (1996) TREEVIEW: an application to display phylogenetic trees on personal $940 \quad$ computers. Comput Appl Biosci 12: 357-358.

941 83. Papazova, D., and Pavlova, A. (1999) Development of a simple gas chromatographic method for 942 differentiation of spilled oils. J Chromatogr Sci 37: 1-4.

943 84. Parsons, M.L., Morrison, W., Rabalais, N.N., Turner, R.E., and Tyre, K.N. (2015)

944 Phytoplankton and the Macondo oil spill: a comparison of the 2010 phytoplankton assemblage 945 to baseline conditions on the Louisiana shelf. Environ Pollut 207: 152-160.

946 85. Passow, U. (2002) Transparent exopolymer particles (TEP) in aquatic environments. Prog $947 \quad$ Oceanogr 55: 287-333.

948 86. Passow, U., Alldredge, A.L., and Logan B.E. (1994) The role of particulate carbohydrate 949 exudates in the flocculation of diatom blooms. Deep-Sea Res part I 41: 335-357.

950 87. Passow, U., Ziervogel, K., Asper, V., and Diercks, A. (2012) Marine snow formation in the 951

89. Piehler, M.F., Swistak, J.G., Pinckney, J.L., and Paerl, H.W. (1999) Stimulation of diesel fuel biodegradation by indigenous nitrogen fixing bacterial consortia. Microbial Ecol 38: 69-78.

957 90. Pinhassi, J., Montserrat Sala, M., Havskum, H., Peters, F., Guadayol, Ó., Malits, A., et al. (2004) 958 Changes in bacterioplankton composition under different phytoplankton regimens. Appl Environ 
Microbiol 70: 6753-6766.

960 91. Ponomarenko, L.P., Stonik, I.V., Aizdaicher, N.A., Orlova, T.Y., Popovskaya, G.I., Pomazkina,

961 G.V., et al. (2004) Sterols of marine microalgae Pyramimonas cf. cordata (Prasinophyta),

962 Attheya ussurensis sp. nov. (Bacillariophyta) and a spring diatom bloom from Lake Baikal.

963 Comparat Biochem Physiol Part B: Biochem Molecul Biol 138: 65-70.

964 92. Prouse, N.J., Gordon, D.C. Jr, and Keizer, P.D. (1976) Effects of low concentrations of oil

965 accommodated in sea water on the growth of unialgal marine phytoplankton cultures. J Fish Res $966 \quad$ Board Can 33: 810-818.

967 93. Radović, J.R., Aeppli, C., Nelson, R.K., Jimenez, N., Reddy, C.M., Bayona, J.M., et al. (2014)

968 Assessment of photochemical processes in marine oil spill fingerprinting. Mar Pollut Bull 79:

$969 \quad 268-277$.

970 94. Riemann, L., Steward, G.F., and Azam, F. (2000) Dynamics of bacterial community

971 composition and activity during a mesocosm diatom bloom. Appl Environ Microbiol 66: 578-

972587.

973 95. Röling, W.F.M., Milner, M.G., Jones, M.D., Lee, K., Daniel, F., Swannell, R.J.P., et al. (2002)

974 Robust hydrocarbon degradation and dynamics of bacterial communities during nutrient-

975 enhanced oil spill bioremediation. App Environ Microbiol 68: 5537-5548.

976 96. Safanova, E.T., Dmitrieva, I.A., and Kvitko, K.V. (1999) The interaction of algae with

977 alcanotrophic bacteria in black oil decomposition. Res Conserv Recycl 27: 193-201.

978 97. Sargian, P., Mostajir, B., Chatila, K., Ferreyra, G. A., Pelletier, E., and Demers, S. (2005) Non979 synergistic effects of water-soluble crude oil and enhanced ultraviolet-B radiation on a natural $980 \quad$ plankton assemblage. Mar Ecol Progr Ser 294: 63-77.

981 98. Sauer, T., and Boehm, P. (1991) The use of defensible analytical chemical measurements for oil 982 spill natural resource damage assessment. Int Oil Spill Conf Proc 1: 363-369.

983 99. Shaw, S.L., Gantt, B., and Meskhidze, N. (2010) Production and emissions of marine isoprene $984 \quad$ and monoterpenes: a review. Adv Meteorol doi:10.1155/2010/408696. 
985 100.Simon, M., Glockner, F.O., and Amann, R. (1999) Different community structure and

986 temperature optima of heterotrophic picoplankton in various regions of the Southern Ocean.

987 Aquat Microb Ecol 18: 275-284.

988 101.Siron, R., Giusti, G., Berland, B., Morales-Loo, R., and Pelletier, E. (1991) Water-soluble

989 petroleum compounds: chemical aspects and effects on the growth of microalgae. Sci Total

$990 \quad$ Environ 104: 211-227.

991 102.Techtmann, S.M., Fortney, J.L., Ayers, K.A., Joyner, D.C., Linley, T.D., Pfiffner, S.M., et al.

992 (2015) The unique chemistry of eastern Mediterranean water masses selects for distinct

993 microbial communities by depth. PLoS One 10: p. e0120605

994 103.Tett, P., and Edwards, V. (2002) Review of harmful algal blooms in Scottish coastal waters.

995 Scottish Environmental Protection Agency Report.

996 104.Thompson, J.D., Higgins, D.G., and Gibson, T.J. (1994) CLUSTAL_X: improving the

997 sensitivity of progressive multiple sequence alignment through sequence weighting, position-

998 specific gap penalties and weight matrix choice. Nucl Acids Res 22: 4673-4680.

999 105.van Eenennaam, J.S., Wei, Y., Grolle, K.C.F., Foekema, E.M., and Murk, AT.J. (2016) Oil spill 1000 dispersants induce formation of marine snow by phytoplankton-associated bacteria. Mar Pollut $1001 \quad$ Bull 104: 294-302.

1002 106.Vargo, G., Hutchins, M., and Almquist, G. (1982) The effect of low, chronic levels of no. 2 fuel 1003 oil on natural phytoplankton assemblages in microcosms: 1. Species composition and seasonal $1004 \quad$ succession. Mar Environ Res 6: 245-264.

1005 107.Vila, J., Nieto, J.M., Mertens, J., Springael, D., and Grifoll, M. (2010). Microbial community 1006 structure of a heavy fuel oil-degrading marine consortium: linking microbial dynamics with 1007 polycyclic aromatic hydrocarbon utilization. FEMS Microbiol Ecol 73: 349-362.

1008 108.Warshawsky, D., LaDow, K., and Schneider, J. (2007) Enhanced degradation of benzo[a]pyrene 1009 by Mycobacterium sp. in conjunction with green alga. Chemosph 69: 500-506.

1010 109.Welshemeyer, N.A. (1994) Fluorometric analysis of chlorophyll a in the presence of chlorophyll 
and pheopigments. Limnol Oceanogr 39: 1985-1992.

1012 110.Wilmotte, A., Van Der Auwera, G., and De Wachter, R. (1993) Structure of the 16S ribosomal 1013 RNA of the thermophilic cyanobacterium Chlorogloeopsis HTF ('Mastigocladus laminosus $1014 \quad \mathrm{HTF}^{\prime}$ ) strain PCC7518, and phylogenetic analysis. FEMS Microbiol Lett 317: 96-100.

1015 111.Wotton, R.S. (2004) The essential role of exopolymers (EPS) in aquatic systems. In: Gibson, 1016 R.N., Atkinson, R.J.A., Gordon, J.D.M. (Eds.), Oceanography and Marine Biology: an Annual $1017 \quad$ Review. CRC Press, pp. 57-94.

1018 112.Yakimov, M.M., Denaro, R., Genovese, M., Cappello, S., D’Auria, G., Chernikova, T.N., et al. 1019 (2005) Natural microbial diversity in superficial sediments of Milazzo Harbor (Sicily) and 1020 community successions during microcosm enrichment with various hydrocarbons. Environ $1021 \quad$ Microbiol 7: 1426-1441.

1022 113.Yakimov, M.M., Timmis, K.N., and Golyshin, P.N. (2007). Obligate oil-degrading marine 1023 bacteria. Curr Opin Biotechnol 18: 257-266.

1024 114.Yang, T., Nigro, L.M., Gutierrez, T., D’Ambrosio, L., Joye, S.B., Highsmith, R., et al. (2016) 1025 Pulsed blooms and persistent oil-degrading bacterial populations in the water column during and 1026 after the Deepwater Horizon blowout. Deep-Sea Res part II 129: 282-291.

1027 115.Zelibor, J.L., Romankiw, L., Hatcher, P.G., and Colwell, R.R. (1988) Comparative analysis of 1028 the chemical composition of mixed and pure cultures of green algae and their decomposed 1029 residues by ${ }^{13} \mathrm{C}$ nuclear magnetic resonance spectroscopy. Appl Environ Microbiol 54: 1051$1030 \quad 1060$.

1031 116.Zhao, B., Wang, H., Li, R., and Mao, X. (2010) Thalassospira xianhensis sp. nov., a polycyclic 1032 aromatic hydrocarbon-degrading marine bacterium. Int J Syst Evol Microbiol 60: 1125-1129.

1033 117.Ziervogel, K., McKay, L., Rhodes, B., Osburn, C.L., Dickson-Brown, J., Arnosti, C., et al. 1034 (2012) Microbial activities and dissolved organic matter dynamics in oil-contaminated surface 1035 seawater from the Deepwater Horizon oil spill. PLoS ONE 7: e34816. 
1051 Table and Figure legends

1053 Table 1. Hydrocarbons biodegraded during enrichment of the phytoplankton (treatment PHY) or 1054 free-living bacterial (treatment BAC) fractions with Heidrun crude oil.

1055

1056 Table 2. Eukaryotic phytoplankton taxa for which genus and/or species designations could be

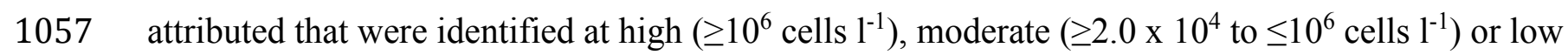
1058 ( $\geq 1$ to $\leq 2.0 \times 10^{4}$ cells $1^{-1}$ ) abundance at Loch Creran during the spring of 2013. The class of each 1059 phytoplankton taxon is shown.

1061 Figure 1. Differences in hydrocarbon ratios (significant results only, Student's T-test, $P<0.05$ ) 1062 comparing live treatments (BAC or PHY) to their respective acidified controls for five characteristic 
1063 parameters indicative of biodegradation: 2-methylnaphthalene/1-methylnaphthalene (2MN/1MN), 21064 methylnaphthalene/(2,6+2,7)-dimethylnaphthalene (2MN/26+27DMN), phenanthrene/9-

1065 methylphenanthrene (P/9MP), $n \mathrm{C} 17 /$ pristane (nC17/pr), $n \mathrm{C} 18 /$ phytane (nC18/phy). Values are 1066 averages of triplicate incubations. Error bars show standard error. The dashed line shows the 1067 division between PHY and BAC treatments.

1069 Figure 2. Chlorophyll $a$ concentrations (solid circles) and bacterial 16S rRNA genes (open circles) 1070 in incubations of the phytoplankton (treatment PHY) or bacterial (treatment BAC) community 1071 amended with Heidrun crude oil (respectively, graphs A and B) or the phytoplankton without any 1072 added oil (treatment CON; graph C). Each point represents the average and standard deviation of 1073 triplicate Chl $a$ or qPCR measurements from independent incubations. Some error bars are smaller 1074 than the symbol.

1076 Figure 3. Composition of bacterial 16S rRNA gene MiSeq reads from incubations of the 1077 phytoplankton (treatment PHY) and free-living bacterial (treatment BAC) community with Heidrun 1078 crude oil, and of the phytoplankton without oil (treatment CON). The relative abundance of taxa 1079 present at $\geq 1 \%$ relative abundance is shown. Sequences were classified to family-level taxonomy 1080 when possible and otherwise a higher-level classification is shown.

1082 Figure 4. Heatmap of all OTUs enriched in the oil-amended incubations (treatments PHY and BAC) 1083 compared to the controls (treatment CON). OTUs were considered enriched if there was a mean 1084 increase of at least $1 \%$ relative abundance (e.g. shift from $1 \%$ to $2 \%$ ) in at least one time point for 1085 replicate incubations, and if the difference was statistically significant $(P<0.05)$. Colour key 1086 indicates square-root normalized relative abundance (\%). A strong succession pattern in the oil1087 amended treatments (P and B) was apparent for members of the Piscirickettsiaceae: OTU-9 1088 (Methylophaga) peaked in relative abundance on day 40 in treatment $\mathrm{P}$, and at day 14 in treatment B; 
1089 and OTU-8 (other Piscirickettsiaceae) peaked in relative abundance on day 14 in treatment P.

$1090 *$ Betaproteobacteria, ${ }^{* *}$ Verrucomicrobia

1091

1092 Figure 5. Neighbor-joining phylogenetic tree based on 16S rRNA gene sequences ( $>1,200 \mathrm{bp})$,

1093 showing the 20 OTUs enriched (in bold) in the oil-amended incubations alongside representatives of 1094 related taxa. Filled circles indicate nodes with bootstrap values (1,000 bootstrap replications) greater 1095 than $90 \%$; open circles indicate bootstrap values greater than $60 \%$. GenBank accession numbers are 1096 shown in parentheses. The scale bar, indicates the number of substitutions per site.

1097 